\title{
Bioactivity of Combination Elephantopus scaber and Sauropus androgynus on the Level of B220 cells of Lymph Node in Pregnant Typhoid BALB/c Mice
}

\author{
Lulut Dwi Nurmamulyosari ${ }^{1}$, Muhammad Sasmito Djati $^{2 *}$, Sri Widyarti ${ }^{2}$ \\ ${ }^{1}$ Master Program of Biology, Faculty of Mathematics and Natural Sciences, University of Brawijaya, Malang, Indonesia \\ ${ }^{2}$ Department of Biology, Faculty of Mathematics and Natural Sciences, University of Brawijaya, Malang, Indonesia
}

\begin{abstract}
Elephantopus scaber and Sauropus androgynus are herbal remedies that contain flavonoids as immunomodulatory agents. This study was aimed to observe the changes in the relative number of $B$ cells in lymph node tissue of pregnant typhoid mice. Mice were divided into seven groups $\mathrm{K}-, \mathrm{K}+$, E. scaber $200 \mathrm{mg} \cdot \mathrm{kg}^{-1} \mathrm{BW}$, E. scaber $150 \mathrm{mg} \cdot \mathrm{kg}^{-1} \mathrm{BW}+\mathrm{S}$. androgynus $37.5 \mathrm{mg} \cdot \mathrm{kg}^{-1} \mathrm{BW}$, E. scaber $100 \mathrm{mg} \cdot \mathrm{kg}^{-1} \mathrm{BW}+$ S. androgynus $75 \mathrm{mg} \cdot \mathrm{kg}^{-1} \mathrm{BW}$, E. scaber $50 \mathrm{mg} \cdot \mathrm{kg}^{-1} \mathrm{BW}+\mathrm{S}$. androgynus $112.5 \mathrm{mg} \cdot \mathrm{kg}^{-1} \mathrm{BW}$, dan S. androgynus $150 \mathrm{mg} \cdot \mathrm{kg}^{-1} \mathrm{BW}$. Mice were dissected on the $12^{\text {th }}$ and $18^{\text {th }}$ day after herbal treatment. Data was analyzed using one way ANOVA $(p<0.05)$ and Duncan. The result show that $E$. scaber combination of $200 \mathrm{mg} \cdot \mathrm{kg}^{-1} \mathrm{BW}$ and $E$. scaber $150 \mathrm{mg} \cdot \mathrm{kg}^{-1} \mathrm{BW}+S$. androgynus $37.5 \mathrm{mg} \cdot \mathrm{kg}^{-1} \mathrm{BW}$ can increase the number of B220 cells $(p<0,05)$ on pregnant mice typoid model.
\end{abstract}

Keywords: B220, Elephantopus scaber, pregnant, Sauropus androgynus, typhoid fever

\section{INTRODUCTION}

Salmonella typhi bacteria can cause typhoid fever [1]. Total 20,000 patients recorded in 2003 died of typhoid fever in Indonesia [2]. The prevalence of typhoid increases each year [3]. Salmonella bacteria is classified as facultative intracellular bacteria, making it difficult for immune system to recognize antigens.

In early primary infection, Salmonella is controlled by the innate immune system. After seven days, the adaptive immune system will start to work [4]. First time with a CD4-T cells activation by binding CD4-T cells, antigenspecific, and MHC class II presented by APC (Antigen Presenting Cell) on lymph nodes. The activated CD4-T cells would secrete cytokines IL-2 (Interleukin-2) which stimulates proliferation of CD8-T cell, B cell, and CD4-T cells itself [5]. CD8-T cells are active will lysis infected cells that recognized by specific antigens presented by MHC class I [6]. CD8-T cells activation occurred along with the decrease of CD62L-T cells [7]. Whereas $B$ cells will produce antibodies that can recognize specific antigens in infected cells and in cooperation with NK (Natural Killer) for lysis of the cells [6].

Previous research showed that $65.4 \%$ of pregnant women exposed to typhoid fever [8]. In pregnant women, the disease can cause

\footnotetext{
* Correspondence author:

Moch. Sasmito Djati

Email : msdjati@ub.ac.id

Address : Laboratory of Animal Physiology, University of Brawijaya, Jl. Veteran Malang, 65145
}

miscarriage because of excessively NK cell lysis. The role of hormones of pregnancy against the maternal immune system is different between pregnant and nonpregnant woman [9].

Antibiotic that cure typhoid fever can be teratogens [10]. It is require a safer alternative to minimize these risks is by using herbs. Plants that have the potential as a medicinal herb is Elephantopus scaber and Sauropus androgynus. Both herbs contain flavonoids and saponins as immunomodulatory $[11,12,13]$. However, it is not known if the two combined herbal will serve as an immunosuppressant or immunostimulant agent, especially in the case of typhoid fever in pregnancy. This study aims to determine the effect of the day pregnancy and combination of extract $E$. scaber and $S$. androgynus on the relative number of $B$ cells in pregnant mice model of typhoid fever.

\section{MATERIALS AND METHODS}

Ethanol Extract Preparation of E. scaber and $S$. androgynus

Preparation of ethanol extract of $E$. scaber and $S$. androgynus based on previous research [14]. Leaf powder E. scaber and S. androgynus obtained from the Material Medica, Batu, East Java. The powder as much as $27.6 \mathrm{~g}$ from each plant was macerated in a glass jar with $70 \%$ ethanol at room temperature and dark for 24 hours. The ethanol extract was filtered and added another $70 \%$ ethanol for 24 hours, it was performed 2 to 3 times. The material is filtered 
and then evaporated at $50^{\circ} \mathrm{C}$ using a vacuum pump evaporator.

\section{Bacteria}

Bacterial isolates of $S$. typhimurium (444-D) was obtained from the Microbiology Laboratory, Faculty of Medicine, University of Brawijaya, Malang. The number of bacteria that is injected as much as $10^{7}$ CFU. $\mathrm{mL}^{-1}$.

\section{Animals and Treatment}

Mus musculus BALB/c pregnant females aged 8 weeks was obtained from PT. Galaxy Science, Jember, East Java. Mice were randomly divided into seven groups with each group consisting of 6 mice (Table 1). The combination of the extract given by gavage from day $1^{\text {st }}$ of pregnancy. Later in the day $5^{\text {th }}$ infected intraperitoneally with $S$. typhimurium, while given the extract until day $12^{\text {th }}$ and $18^{\text {th }}$ of pregnancy, and mice dissected for lymph node organs.

Table 1. Treatment Group

\begin{tabular}{cccc}
\hline \multirow{2}{*}{$\begin{array}{c}\text { Treatment } \\
\text { group }\end{array}$} & \multirow{2}{*}{ Infection } & \multicolumn{2}{c}{ Extract Powder (mg.kg $\mathbf{~}^{-1}$ BW) } \\
\cline { 3 - 4 } & & E. scaber & S. androgynus \\
\hline $1(\mathrm{~K}-)$ & - & - & - \\
$2(\mathrm{~K}+)$ & + & - & - \\
3 & + & 200 & - \\
4 & + & 150 & 37.5 \\
5 & + & 100 & 75 \\
6 & + & 50 & 112.5 \\
7 & + & - & 150 \\
\hline
\end{tabular}

Note: Group 1 and 2 use NaCMC $0.05 \%$, Infection $=10^{7}$ CFU. $\mathrm{mL}^{1}$ S. typhimurium

\section{Lymphocytes Isolation and Flowcytometry Analysis}

After treatment, mice were dislocated and lymphocytes were isolated from lymph node to determine the relative quantity of B220. The lymph nodes were crushed and filtered using a wire. The cell suspension was transferred into a $15 \mathrm{ml}$ centrifuge tube and centrifuged $2500 \mathrm{rpm}$ for 5 minutes $4^{\circ} \mathrm{C}$. Pellets was added $50 \mu \mathrm{L}$ of monoclonal antibody anti $\mathrm{B}_{220^{+}}$(BioLegend \& No Cat. 109813) with concentration $0.01 \mathrm{mg} \cdot \mathrm{mL}^{-1}$. After transferred into a cuvet, cell suspensions was analysed using flow cytometry (BD Bioscience FACSCalibur ${ }^{\mathrm{TM}}$ ).

\section{Data analysis}

This study used a factorial completely randomized design (factorial CRD), with the first factor extract was dose combinations and the second factor was the day of pregnancy. Data was analyzed by one-way ANOVA with $p=0.05$ followed by Duncan as further testing.

\section{RESULT AND DISCUSSION}

The results showed that the extract treatment significantly increase the relative number of B220 cells in lymph node pregnant mice model of typhoid fever. Furthermore, based on Duncan test, on the $12^{\text {th }}$ day of pregnancy there is a difference in the mean number of cells B220 relatively significant among pregnant infected, with normal pregnant group E. scaber extract 200 mg. $\mathrm{kg}^{-1} \mathrm{BW}$ as well as combinations of $E$. scaber $150 \mathrm{mg} \cdot \mathrm{kg}^{-1} \mathrm{BW}$ and S. androgynus $37.5 \mathrm{mg} \cdot \mathrm{kg}^{-1}$ BW (Fig. 1).

The relative number of cells $\mathrm{B} 220$ on the $12^{\text {th }}$ day indicates the infections in pregnant mice are lower than without infection. It shows that when infection occurs, the immune system of pregnant mice decreased. This is because the cytokines of lymphocytes decreased during pregnancy when activated monocytes and granulocytes [15]. Monocytes and granulocytes are necessary for the first defense in the $S$. typhimurium infection for the first 7 days as the innate immune system [4]. The number of CD4 and CD8-T cells in pregnant mice infected with $S$. typhimurium was significantly decreased compared with non-pregnant mice [9]. Other study also found the decrease number of CD4-T cells in infected pregnant mice, although the difference was not significant [16].

However, number of CD4 and CD8 T cells in the pregnant condition maintained to be low by hormones that increase during pregnancy, e.g. progesterone, estrogen, and prolactin. Another immune system is maintained low NK cell [17]. The defense mechanism through a reduction in cytokine production, such as IFN $\gamma$, in this case progesterone is immunosuppressive [18].

The E. scaber extract $200 \mathrm{mg} \cdot \mathrm{kg}^{-1} \mathrm{BW}$ as well as combinations of $E$. scaber $150 \mathrm{mg} \cdot \mathrm{kg}^{-1}$ BW and S. androgynus $37.5 \mathrm{mg} . \mathrm{kg}^{-1} \mathrm{BW}$ showed immunostimulatory activity. The activity can be viewed through an increase in the number of B220 cells compared to infected pregnant mice. The increase was due to the flavonoids in E. scaber were able to increase production of the cytokine IL-2, IL-4, and IL-1 which stimulate the proliferation and differentiation of $T$ cells and $B$ cells [19]. Increasing number of B220 cells that occurs is not significantly different from the conditions of pregnant mice without infection. This shows that the extract on both combination stabilizes the immune system such as required in pregnant mice to maintain pregnancy. 
But if the extract is carried out continuously, it resulting decline in the immune system. This can be seen by administration of a combination of extracts was not significantly different from infected pregnant mice. Based on the average number of cells B220, it can be concluded that the optimum dose to stabilize the immune system required for pregnancy is the $E$. scaber extract $200 \mathrm{mg} \cdot \mathrm{kg}^{-1} \mathrm{BW}$ as well as combinations of E. scaber $150 \mathrm{mg} . \mathrm{kg}^{-1} \mathrm{BW}$ and S. androgynus $37.5 \mathrm{mg} . \mathrm{kg}^{-1} \mathrm{BW} 12^{\text {th }}$ day of pregnancy.

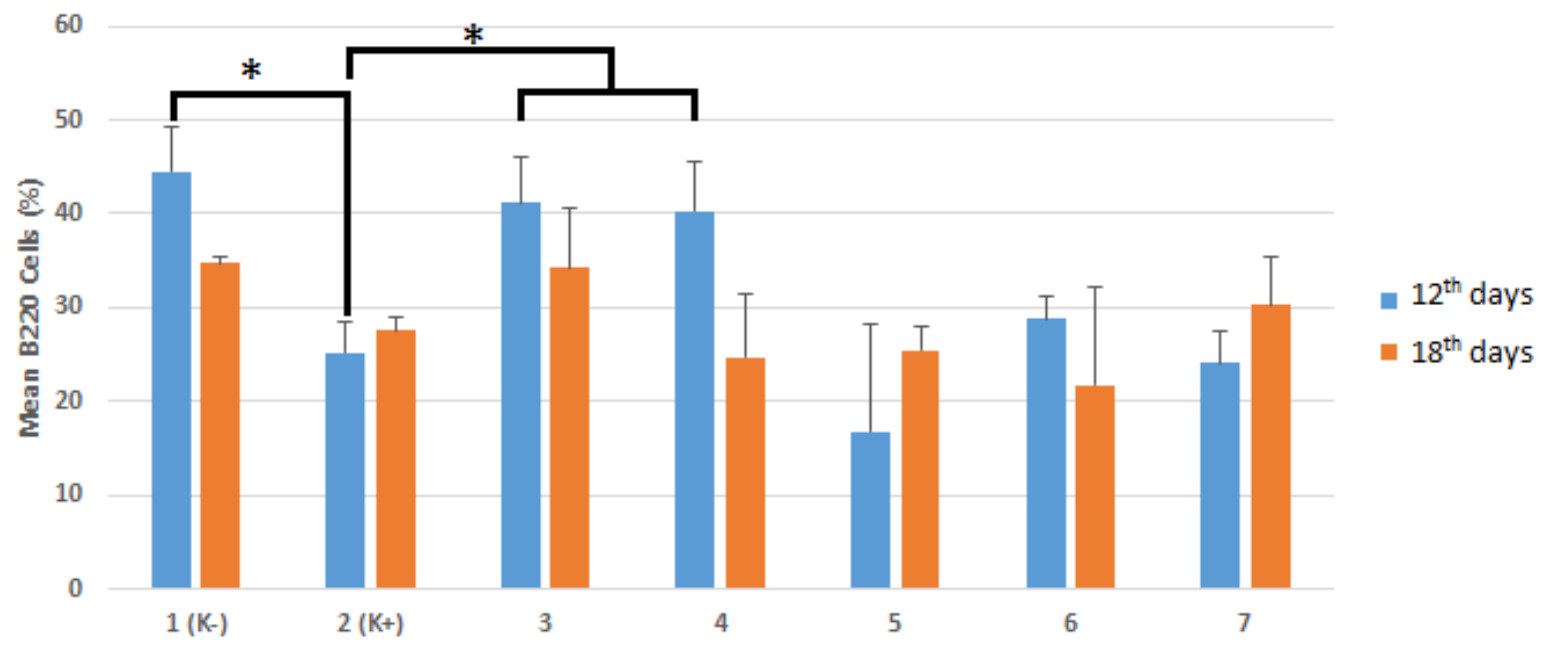

Figure 1. The relative number B220 cells after administration of a combination of extracts of $E$. scaber and S. androgynus (mg. $\mathrm{kg}^{-1} \mathrm{BW}$ ). An asterisk $\left({ }^{*}\right)$ indicates that on the $12^{\text {th }}$ day, the positive control was significantly different with negative control, giving a combination of $E$. scaber extract $200 \mathrm{mg} \cdot \mathrm{kg}^{-1} \mathrm{BW}$, as well as E. scaber $150 \mathrm{mg} \cdot \mathrm{kg}^{-1} \mathrm{BW}$

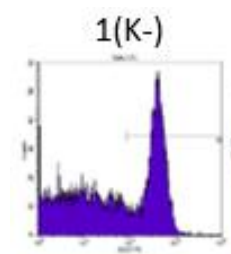

5

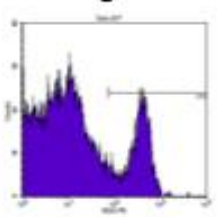

a

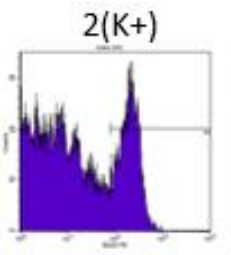

6
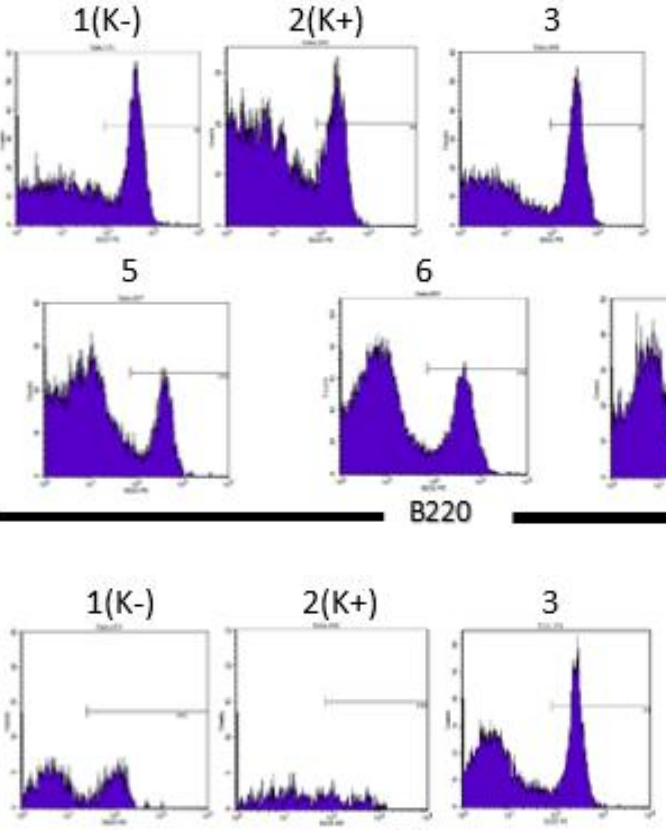

5

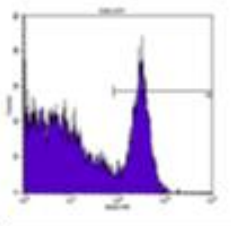

b

\begin{abstract}
$2(\mathrm{~K}+)$
\end{abstract}

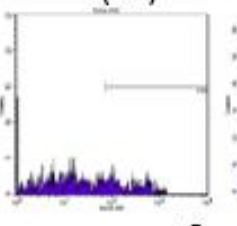

6

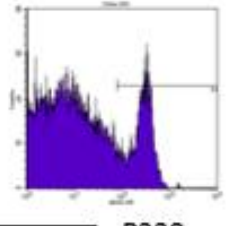

B220

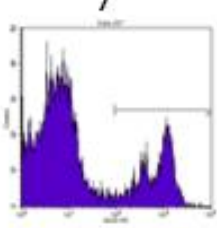

3

4
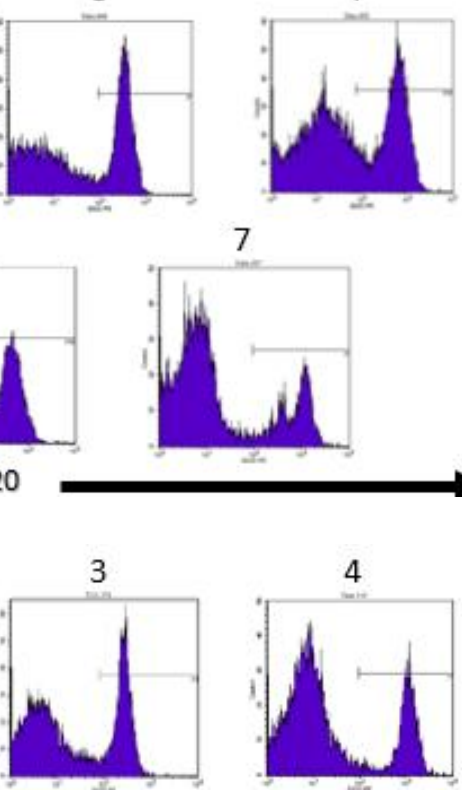

4

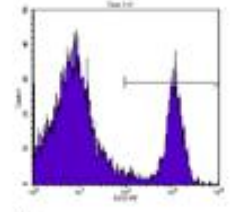

7
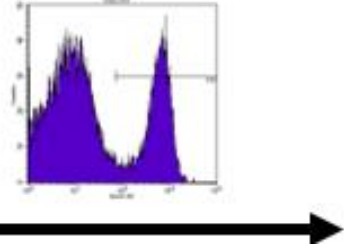

Figure 2. Percentage of relative cell number B220 after giving treatment. (a) $12^{\text {th }}$ day of pregnancy; (b) $18^{\text {th }}$ day of pregnancy. 


\section{CONCLUSION}

The ethanolic extracts combination of $E$. scaber and $S$. androgynus showed a significant effect on the number of B220 cells with optimum doses of the administration of a combination of extracts of $E$. scaber $200 \mathrm{mg} \cdot \mathrm{kg}^{-1} \mathrm{BW}$, followed by E. scaber $150 \mathrm{mg} \cdot \mathrm{kg}^{-1} \mathrm{BW}+\mathrm{S}$. androgynus 37.5 $\mathrm{mg} . \mathrm{kg}^{-1} \mathrm{BW}$.

\section{ACKNOWLEDGEMENT}

We gratefully acknowledge to Prof. Muhaimin Rifa'i, S.Si., Ph.D.Med.Sc which provide antibody for this research.

\section{REFERENCES}

[1] Muliawan, S.Y., L.H. Moehario, P. Sudarmono. 2000. Validitas pemeriksaan uji aglutinin $\mathrm{O}$ dan H S. typhi dalam menegakkan diagnosis dini demam tifoid. Universitas Trisakti. Jakarta.

[2] Dewi, P. 2007. Pengaruh pemberian ekstrak lidah buaya (Aloe vera) terhadap proliferasi limfosit pada mencit BALB/c yang diinfeksi Salmonella typhimurium. Scientific Paper. Faculty of Medicine. Diponegoro University. Semarang.

[3] Eddy, S., Suharto, U. Hadi, Nasronudin. 2007. Demam tifoid deteksi dini dan tata laksana, Buku ajar ilmu dalam. Airlangga University Press. Surabaya.

[4] Ravindran, R., S.J. McSorley. 2005. Tracking the dynamics of T-cell activation in response to Salmonella infection. Immunology. 114. 450-458.

[5] Luu, R.A., K. Gurnani, R. Dudani, R. Kammara, H. van Faassen, J. C. Sirard, L. Krishnan, S. Sad. 2006. Delayed expansion and contraction of CD8_T Cell response during infection with virulent Salmonella typhimurium. J. Immunol. 177. 1516-1525.

[6] Abbas, A.K., A.H. Lichtman, J.S. Pober. 2000. Cellular and molecular 4 Ed. W.B. Saunders Company. USA.

[7] Huang, C.H., C.Y. Ku, T.R Jan. 2010. Diosgenin, a plant-derived sapogenin, enhances regulatory T-cell immunity in the intestine of mice with food allergy. J. Nat. Prod. 73. 1033-1037.

[8] Chessed, G., I. James, A.B. Yako, K. Egbucha. 2013. Prevalence of typhoid fever infection among pregnant women at the antenatal care unit of specialist hospital, Yola North Local Government Area, Adamawa State, Nigeria. Int. Sci. Res. J. 4(2). 93-99.
[9] Pejcic-Karapetrovic, B., K. Gurnani, M.S. Russell, B.B. Finlay, S. Sad, L. Krishnan. 2007. Pregnancy impairs the innate immune resistance to Salmonella typhimurium leading to rapid fatal infection. J. Immunol. 179. 6088-6096.

[10] Gondo, H.K. 2007. Penggunaan antibiotika pada kehamilan. Wijaya Kusuma.1(1).57-62.

[11] Subramanian, A., A.S. Kumar, S.K. Suja, M. Sudarshan, A. Chakraborty. 2014. Antioxidant and free radical scavenging activity of annular and seasonal ayurvedic medical plants Elephantopus scaber L. and Biophytum sensitivum DC. Int. J. Pharm. Biol. Chem. Sci. IJPB(S). 3(1). 6-17.

[12] Francis, G., K. Zohar, P.S.M. Harinder, B. Klaus. 2002. The biological action of saponins in animal systems. British J. Nutr. 88. 587-605.

[13] Selvi, S., A. Baskar. 2012. Evaluation of bioactive component and antioxidant activity Sauropus androgynus plant extract using GC-MS analysis. IJPB(S). 12(2). 65-67.

[14] Marmi. 2010. Aktivitas biologi ekstrak Tapak Liman (Elephantopus scaber, L) terhadap perkembangan limfosit pada mencit Balb/C. Master Thesis. Dept. of Biology, University of Brawijaya. Malang.

[15] van Nieuwenhoven, L.A.V., A. Bouman, H. Moes, M.J. Heineman, L.F.M.H. De Leij, J. Santema, M.M. Faas. 2003. Endotoxininduced cytokine production of monocyte of third-trimester pregnant women compared with women in the dolicular phase of the menstrual cycle. Am. J. Obstet. Gynecol. 188(4). 1073-1077.

[16] Roffico, M.S. Djati. 2014. Efektivitas pemberian ekstrak ethanol daun Polycias obtusa dan Elephantopus scaber terhadap modulasi sel $\mathrm{T} \mathrm{CD}^{+}$dan $\mathrm{CD} 8^{+}$pada mencit bunting BALBc. Jurnal Biotropika. 2(3). 174180.

[17] Dosiou, C., L.C. Giudice. 2005. Natural Killer cells in pregnancy and recurrent pregnancy loss: endocrine and immunologic perspective. Endocr. Rev. 26(1). 44-62.

[18] Choi, B.C., K. Polgar, L. Xiao, J.A. Hill. 2000. Progesterone inhibits in vitro embryotoxic Th1 cytokine production to tropoblast in women with recurrent pregnancy loss. Hum. Reprod. 15(1). 46-59.

[19] Azizah, N.F. 2011. Efek pemberian tapak liman terhadap hematopoeisis mencit model anemia. Master Thesis. Dept. of Biology, University of Brawijaya. Malang. 